\title{
The private equity business model and associated strategies for HRM: evidence and implications?
}

\section{Ian Clark}

To cite this article: Ian Clark (2009) The private equity business model and associated strategies for HRM: evidence and implications?, The International Journal of Human Resource Management, 20:10, 2030-2048, DOI: 10.1080/09585190903175605

To link to this article: https://doi.org/10.1080/09585190903175605

\section{Published online: 23 Oct 2009.}

Submit your article to this journal $\pi$

LII Article views: 357

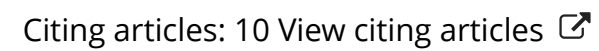




\title{
The private equity business model and associated strategies for HRM: evidence and implications?
}

\author{
Ian Clark* \\ International Management and Organization Research Group, Birmingham Business School, \\ The University of Birmingham, Edgbaston, Birmingham, UK

\begin{abstract}
Are private equity firms significant actors in the UK market for corporate control? Do they represent a new organizational form befitting a new business model? What are the direct and indirect pressures on management that flow from the diffusion of this business model and its associated organizational form? In terms of human resource management does acquisition by private equity have a significant or negligible effect? This paper looks at the development and diffusion of private equity and the 'take private' private equity business model (PEBM) and the effects of these on the management of HR. In addition to this the paper evaluates the PEBM within comparative institutional approaches to international business and HRM.
\end{abstract}

Keywords: business model; HRM; national business systems; private equity; shareholder value

\section{Introduction}

Soothsayers and futurologists in the academic community have a vested interest or stake in proclaiming the new. Other members of the academic community-sometime, historical materialists, institutionalists or those who remain doggedly unfashionable-continue to proclaim the old in proximate terms such as embeddedness, historically informed or historical specificity. This divergence of approach is at its zenith when a new conceptual category such as 'varieties of capitalism' appears to explain why different economies (in pre business school language mixed economies and free market economies) are more or less successful in terms of economic efficiency and industrial democracy. The Zen quality of business systems theory and the varieties of capitalism thesis give both soothsayer and dinosaur the opportunity to proclaim the virtues of their position in the face of headline evidence to the contrary.

A key analytical, methodological and perspective issue is that it is not only possible but essential to identify and work within the distinctive varieties of managerial capitalism. Based on some form of systemic cultural and institutional coherence which, in the past, formed the bases of successful economic performance and improved social distribution, these varieties fuel the academic industry sometimes beyond but more usually within the business school format. Academics are fuelled in the same way that the ASBO industry, the Green industry, the Holocaust industry and the Slavery industry separate the interests of professional purveyors therein from those who suffer the misery of anti-social behaviour, extra taxation, holocaust survival and racial discrimination. Discussion of the merits and de-merits of different varieties of capitalism in distinctive business systems is

*Email: i.a.clark@bham.ac.uk 
not only useful to academics, it is vital for ones scholarly and research career but it is of distinctly less importance to customers of, employees in and suppliers to businesses that are subject to the private equity business model (PEBM).

Accordingly the paper addresses three issues. First, the emergence of private equity firms as significant actors in the UK's market for corporate control does trail a new organizational form and associated business model which is being diffused across other European varieties of capitalism. Second, potential pressures on management that flow from the diffusion of this new business model and associated organizational form are both direct and indirect. Direct in that a firm acquired by a private equity investor is likely to be subject to significant financial, commercial and organizational re-structuring. Indirect in that management in firms that are circled by private equity investors may have to adopt private equity type strategies to persuade shareholders or family owners not to sell out. Potentially, this pressure leads to aspects of the PEBM becoming a best practice innovation in non-private equity backed firms. Third, acquisition by private equity may have a significant or negligible effect on HRM at firm level. Management remuneration may be boosted by the diffusion of agency inspired performance management incentives, whereas employees may become subject to tighter and more onerous technical and bureaucratic controls with growth in the size of peripheral employees as the firm is downsized and slimmed to it core competences. Alternatively, the impact of shareholder value and the PEBM on HRM may be positioned in the framework of the diffusion of country of origin effects versus host country effects, (see Ferner et al. 2004) sometimes without convincing empirical support. (For critical analysis demonstrating the embeddedness of equity markets in the British business system see Pendleton and Gospel 2005, pp. 59-83.)

In summary, this paper looks at the development and diffusion of private equity, the private equity 'take private' phenomenon and the associated PEBM. After a discussion of research methods the following section addresses the PEBM and the operational rationale of private equity firms. Section three inserts the diffusion of the PEBM within the comparative institutional and varieties of capitalism approach to the evaluation of international business. This is followed by discussion and evaluation of managerial and HR changes associated with private equity control or ownership which is supported by empirical evidence gathered from case studies and a sector mapping survey.

\section{Methodology}

The empirical material drawn on in this paper flows from several separate yet interrelated research projects where the term 'private equity' or 'equity investors' was first encountered in research examining business and HR strategies in American multinational firms, Colling and Clark (2002). ${ }^{1}$ These references were subsequently followed up and further developed in work commissioned by the Financial Services Authority (FSA) and the Treasury Select Committee (TSC) in its examination of private equity, (FSA 2006; Clark 2007; TSC 2007). The commissioned work including the subsequent case study material examines the extent to which acquisition, ownership or control by private equity results in patterns of management in job regulation which are characteristic of the private equity stereotype, particularly in its 'take private' variant. The findings presented in section four draw on 25 qualitative semi-structured case study interviews with interview respondents from the British Venture Capital Association (BVCA), the FSA, two of the largest private equity funds based in the UK that specialise in 'take private' deals, legal officers and regional convenors as well as the general secretaries of the GMB and UNITE trade unions, fund managers and lay trade union representatives and workers in firms' that 
are owned or controlled by private equity. Access to trade union officials was particularly useful as this revealed employer material on human resource and employment relations strategies that has proved very difficult to acquire or corroborate on company web sites. These interviews brought to the surface details of buy-out strategies and associated HR strategies that survey approaches may fail to reveal, for example the extent to which private equity firms use 'union busting' consultants such as the Burke Group. There are, however, limitations to the empirical material; it was at times difficult to get 'management' interviews in some firms as opposed to fund management 'management' appointees. This limitation is mitigated by the fact that in the Select Committee sessions fund managers from four of the UK's largest private equity funds appeared content with the criticism of some of their actions in The AA, for example, stating that they had done nothing unlawful, see, Treasury Select Committee Tenth Report, (TSCTR) oral and written evidence, (2007). In addition to this primary research previously published material is drawn from sources as diverse as the BVCA, regulatory authorities such the FSA and the take over panel, other government departments and private equity funds themselves.

\section{Private equity and the private equity business model in the British business system}

\section{Defining the private equity business model}

Traditionally publicly quoted firms raise investment funds from two sources. First, on London's stock exchange public equity market and second sometimes this is supplemented by debt based funds in the form of debentures, which in the event of default or bankruptcy give debt holders creditor status over company assets. In contrast to this established pattern of investment funding there has recently been significant growth in capital flowing into private equity funds. This growth is so extensive that the private equity sector within Britain's capital market now provides a specific business model designed to support start-up and established businesses. It involves innovative commercial and operational strategies centred on sophisticated financial management and debt leverage that aim to enhance company efficiency but on a shareholder not a stakeholder model of corporate governance. To be precise private equity fund management partnerships are one part of a highly stratified fund management and venture capital sector that comprises three components. First, a large group of small entrepreneurial firms which focus on smaller domestic transactions, more popularly these providers are often termed venture capitalists who look to support promising business ventures in search of start-up and roll-out capital; the role of which as been recently vulgarised in the BBC television programme 'Dragon's Den'. A second group of larger firms tend to focus on more mid-sized domestic transactions in the form of management buy-outs or in some cases management buy-ins to established but predominantly private, that is unlisted British based businesses. A third group comprising fewer but much larger members is dominated by five businesses The Carlyle group, Blackstone, KKR, Perimira and 3i. These firms undertake very large domestic and international transactions on the private equity business model and it is this group of firms with which this paper is primarily concerned.

The contemporary activity of these firms and their fund managers extends beyond private firms or small firms seeking start-up capital. Recently the private equity sector has become renowned for 'take private' deals whereby via a combination of equity and bank debt private equity firms acting for themselves, a consortium of banks or individuals buy-out all the publicly quoted shares in a company taking the company private. 
So operationally private equity firms establish and operate collective investment schemes and advise on, assess and manage investment deals for clients, (FSA 2006, p. 79). These groups are predominantly funded by institutional investors such as pension funds, commercial and retail banks, insurance companies, government agencies and local authorities. Private equity firms focus on the legal duty to maximise value for their investors and shareholders and may break-up an acquired company selling up to $50 \%$ of its assets to support debt levels incurred in a purchase, (see Clark 2007).

To summarise many private equity firms are unlisted limited partnerships which are made up of general partners - the fund managers and limited partners - the investors who provide the bulk of the investment capital for the fund. The PEBM rests on the sophisticated use of financial engineering to transform 'cheap' or 'underperforming' businesses. Theoretically, private equity partnerships are freed from the burden of quarterly reports and associated transparency and risk averse, that is, discretionary management. Therefore they can manage a business run on the PEBM to emphasise governance principles based on direct ownership and agency wherein management control reflects stock ownership rather than the impact of a separation between ownership and control. The theoretical basis of the PEBM rejects the utility of managerial theories of the firm that emphasise managerial discretion and shareholder deference to professional salaried managers (Means 1930; Berle and Means 1932; Marris 1964; Williamson 1964, 1967; Chandler 1977). The alternative emphasis on agency theories (Alchian and Demsetz 1972; Jensen and Meckling 1976) and transaction cost theories (Williamson 1975) focuses not on institutionally embedded patterns of efficiency and organizational capability in national variants of managerial capitalism but its waste and inefficiency for shareholders. Thus, within the PEBM there is a contractual approach to management and returns to investment that in effect takes the form of a partnership agreement between fund managers and professional institutional investors.

In crude terms the PEBM is based on debt and leverage whereby an acquisition is actually debt-funded by its own assets such as the sale and lease back of property portfolios. For example, one of the first moves that private equity buyers make is to split an acquisition into an operating company and a property company with the former selling the latter and then leasing it back. One result of this is that owners and managers become 'better managers' because debt levels give them an incentive to perform in order that cash-flow is sufficient to meet interest payments on debt incurred in the primary purchase and the sale and lease back of property (Jensen 1989). Private equity practitioners and their peak associations such as the British Venture Capital Association and the European Venture Capital Association argue that the PEBM is an increasingly dynamic and efficient component of the capital market that offers a compelling business model with the potential to deliver substantial reward to general and limited partners and their investors, management in an acquired firm and current and future pensioners whose income is invested in private equity.

Beyond the relentlessly up-beat advocacy of the PEBM described above there is a downside. An alternative way to describe private equity acquisition and the PEBM is one that asset strips and seeks to reduce operating costs because the model is inherently short-termist in that private equity investors must make their investment attractive to future buyers. An acquisition must be attractive to sell-on in order that fund managers can secure a return for their investors. More significantly there is a distributional and taxation question which in recent times has proved particularly thorny for supporters of private equity. Remuneration packages for senior management in private equity controlled firms are often switched to salary plus equity investment packages and similarly for fund 
managers share portfolio dividend income is classed as a capital gain and if shares are owned for a period of 2 years pay tax at $18 \%$ rather than $40 \%$ (the rate was only $10 \%$ before April 2008). Similarly interest on debt incurred by fund managers to support an acquisition can be written off against tax. Last, the PEBM rests on a '2 and 20' reward model; a transaction cum management fee of up to $2 \%$ of the fund invested in the firm per annum and a $20 \%$ performance cut of any profits triggered once returns exceed a defined level. In the language of the neo-classical theory of the firm 2 and 20 represents a new form of leakage from the system or a new inclusion in normal profit. As some critics have argued once the real numbers of 2 and 20 are discounted the efficiency of plc firms and PEBM based firms is comparatively equal, (see Folkman, Froud, Sukhdev and Williams 2006; Froud and Williams 2007; GMB TSC 2007).

The innovative quality of the PEBM centres on more explicit investor engagement in the management of their investment which has a twofold rationale: first, to establish adequate systems to monitor corporate performance and second and directly related to realise potential in the form of high rates of return - 20-25\% - on risky investments. It is the risk associated with this type of investment that requires investor engagement beyond purely financial measures in corporate governance to deal with the agency problem; that is investor engagement aims to reconcile the effects of the separation between management and finance, (see Shleifer and Vishny 1997, p. 773). By devising and diffusing systems of performance management that are designed to fuse the interests of principal and agent, agents can be incentivised or disciplined to maximise performance in pursuit of the principles' interest.

\section{Private equity investor engagement: organizational forms and re-structuring}

Private equity fund managers are not magicians but they very nearly are; the PEBM operates in a highly leveraged manner meaning that the debt component as a percentage of an acquisition is very high - up to $70 \%$ in some cases. The slight of hand is evident in two ways, on the one hand strategically in terms of exit. Fund managers aim to sell-on firms they acquire within a 5 year time frame often through a new public offering of shares once again returning a business to the listed market. In simple terms this will enable private equity partners to re-pay their debt to investors, secure their tax breaks but pass on the firm's debt. For example, debts that result from sale and lease back of property portfolios or an under-funded pension scheme are easily passed to a new firm. On the other hand operational slight of hand involves extracting value for shareholders and investors by cutting costs to improve margins, selling off or out-sourcing the management of some assets to reduce debt, for example HR can be out-sourced on a shared business model. In terms of employment relations theoretically and empirically this is achieved by harder HRM and more broadly moving towards lower road strategies for workplace agreements on substantive and procedural terms and conditions of employment.

While discussion of private equity as a new type of investment fund is not contentious, the argument that a PEBM is emerging is more contentious for four reasons. First, as this paper aims to make clear, the model is unresearched in any systematic manner and, to be balanced, so are the claims of practitioners who support its diffusion as are the claims of its detractors. Second, because of this the extent to which the PEBM is viable in the longer term is questionable but while this is an unknown the indirect effects of the PEBM do appear even at this stage to becoming embedded in contemporary business practice. For example, the popularity of funding acquisitions on the basis of asset sales and the use of share buy backs and re-capitalisations as the precursors of special dividend payments 
to private equity owners. Third, while the model may not be viable in the longer term the consequences of its deployment for employees both in work and those who are retired will be evident over the long term as more stringent agency influenced HR strategies are unlikely to be wound up by future owners, whereas pension liabilities and deficits remain on the balance sheet of businesses once owned by private equity. Last, many practitioners across all types of business system see the PEBM as an example of the superiority of Anglo-American business strategies and the applicability of this across different forms of capitalism. In contrast to this, politicians, trade unions and some business associations in coordinated business systems see the PEBM as problematic. However, the evidence suggests that most if not all business systems have a nationally based private equity presence greater than one would expect. This is particularly the case where the presence takes the form of sovereign wealth funds controlled by the central state or ruling families as in the cases of China and Dubai.

\section{The PEBM and the comparative business systems approach and new institutionalism}

The two approaches to institutional theory, one centred on the new institutionalism of organizational analysis associated with DiMaggio and Powell, $(1983,1991)$ and the other grouped around the business systems varieties of capitalism approach associated with Whitley $(1992,1999)$ and Hall and Soskice (2001) emphasise how business organizations adapt to institutional environments. The new institutionalism strand of research concentrates on the global diffusion of particular business strategies, associated business models and managerial practices such as shareholder value and the PEBM. A key conceptual and empirical issue relates to the extent to which 'global diffusion' refers to managerial and organisational concepts that become subject to local variation or the extent to which business strategies, practices and models become more similar on a global scale. The isomorphic pressures to adopt similar solutions in the same situation, for example short term pressures for shareholder returns can operate at firm level or business system level. Institutional pressures operate at firm level in coercive, mimetic and normative forms. Management in non-private equity firms may have to compare themselves to competitor firms in the same sector which are managed on the PEBM, this may lead to mimetic pressures to copy or benchmark against practices in these firms. In turn this may lead to normative pressures whereby practices associated with the PEBM become 'best practice' or at least aspirational for non private equity controlled firms. These firm level pressures exist separately from competitive isomorphism at the level of the business system which necessarily assumes and requires the presence of more market oriented competition. The presence of competitive and institutional isomorphism suggests globalisation of practices whereas the presence of either competitive or institutional isomorphism suggests that there is space for local adaptation of global practices.

The business systems and varieties of capitalism strands of research reflect the embeddedness of local practices and attempt to empirically ground theoretical arguments about the independent role of embedded institutions in shaping economic and political outcomes. Here differences in national level institutions refract common economic pressures differentially. That is, institutional trends, for example towards shareholder capitalism and the adoption of the PEBM are mediated by national institutional arrangements. This position casts doubt over convergence based arguments that proclaim the standardisation of global practices. Hall and Soskice (2001) outline a theory of purely contractual arm's length market coordination in what they term contractual coordination 
in liberal market economies and extra contractual institutional regulation in liberal coordinated economies. The depth of embeddedness in different traditions establishes patterns of institutional complementarities that in turn encourage different forms of competitive advantage. For example, in the contemporary period light touch regulation in the UK and USA appears to support job creation and business start-ups and the diffusion of new business models such as PEBM. Alternatively, in Germany institutionally inclusive and consequently less conflict bound job regulation and state regulation and enforcement in vocational training and development have helped to secure the retention of a comparatively high productivity manufacturing sector.

In contrast to Hall and Soskice, Whitley $(1992,1999)$ develops a series of institutional characteristics for the comparison of different business systems. These range from the nature of the firm as a contractual actor and patterns of ownership coordination and control in different societies to patterns of non-ownership coordination and the management of employment relations. Non-ownership coordination refers to the extent to which established rules and common codes of conduct reflect collective goals as agreed in inter-firm networks and business federations which can be cooperative or competitive. For example in Germany there is currently some debate within the business class about the utility of shareholder value approaches and the PEBM. Some firms are subject to private equity ownership and actively advocate the PEBM, for example Deutsche Telecom, whereas others do not, arguing the importance of national control for core businesses and the implications of foreign ownership for embedded patterns in, and systems of, training and development, for example BMW.

While apparently theoretically authoritative and empirically proven, the varieties and comparative institutional theses do suffer from determinism in respect of how different approaches develop, persist and change over time. As early as 2000 the emergence of a trend towards international adoption of shareholder capitalism and associated practices such as the diffusion of the PEBM was identified as possessing the potential to create new types of relationships for organisations, managers and the management of employment relations in Anglo-American market economies and continental coordinated economies, (Dore 2000; O'Sullivan 2000, pp. 154-164, 280-282). Some of these relationships are now evident at firm level in the UK but are also evident across different types of business system. For example, as controlling owners of domestic and multinational firms' private equity investment partnerships differ significantly to more traditional models of ownership which have developed historically within national pathways to industrial capitalism. Private equity firms are only accountable to capital markets with general partners and fund managers emerging as a new elite removed from the constraints of any one business system, for example in 2005 private equity funds based in the British business system only raised $21 \%$ of their capital in the UK with $45 \%$ coming from the USA and continental based providers (in the main France and Germany) in stakeholder business systems providing a further 22\%, (FSA 2006, p. 13). This evidence suggests further dominance by international finance capital in the market for corporate control in the UK with investors in stakeholder business systems actively supporting private equity albeit not in the home economy.

A significant theoretical and empirical discontinuity exists between the two broad strands of institutional analysis; at system level embedded institutions are presented as central mechanisms that shape employer, managerial and employee behaviour. However, in contrast to this focus on embeddedness, at firm level the focus of analysis in employment relations has shifted to the evaluation of the firm as a strategic actor that can shape its own strategic and operational environment, (Frege 2005, pp. 189-193; 
Heery and Frege 2006). The discontinuity borders on the tautological; while shareholder value and the PEBM appear as significant factors in corporate governance the evaluation of employment relations is compromised because the PEBM is not readily evaluated in theory or empirically. Indeed, at firm level the ways in which business strategy is shaped by the PEBM is unclear other than references to the institutional configuration of a business system; short-termism in the case of the UK and the USA. Similarly headline discussion of the PEBM in a coordinated business system such as the German one suggest significant political opposition and operational difficulty due to the nature of family shareholdings and liquidity in the form of block controlled bank credit rather than open and dispersed stock market equity.

The discontinuity in theoretical and empirical evaluation at business system and firm level is manifest because what is less clear in general evaluation of the varieties of capitalism and business systems approaches is that 'embeddedness' refers to different things in different types of system. In Anglo-American economies (Australia, Canada, Ireland, the UK, the USA and New Zealand, see Freeman, Boxall and Haynes 2007) embeddedness relates to a common cultural descent and lineage and a commonality of economic behaviour and political attitudes that support market based systems and comparatively small governments. In contrast to this in liberal coordinated continental European economies embeddedness relates less to system level and the historically derived state tradition and more to the interdependency of relations between financial, education, industrial relations and production systems - but at firm level - that follow on from economic and political coordination.

The discontinuity continues even though the term 'managing for shareholder value' is widely diffused in the evaluation of international business and international and comparative HRM. As a key measure of business performance (managing for) shareholder value presumes and promotes competitive isomorphism - convergence - in business strategies and policies that prioritise shareholder interests in short term financial results and improvements in share price that reflect a higher monetary value of a business. Empirically, the substantive effects at organisational or firm level of the rhetoric of SHV in coordinated systems remains an open question that is it lacks substantive institutional isomorphism. There is some evidence though that at firm level the organisational focus on labour as a cost plus productive resource and source of competitive advantage will be eroded where shareholders become the more dominant stakeholder, (see Clark 2006).

Discontinuity and confusion in analysis will persist because 'managing for shareholder value', private equity and the PEBM and implicit evaluation of firm level and business system level effects reveals only part of the picture. What remains largely hidden is that the PEBM and the impact of private equity funds as institutional investors is the driver behind the move to shareholder value as a key measure of corporate performance. Thus, the PEBM is significant not necessarily as a substantial empirical presence but because it represents the missing competitive and institutional innovation which O'Sullivan (2000, p. 2) identified as the limiting factor in the diffusion of shareholder capitalism and its sustainability in the United States and Germany. O'Sullivan identified the sustained success of retain and reinvest approaches to mass production, managerial capitalism and associated HR strategies in the American business system as resting on its model of innovation at business system level, its managerial theory of the firm and a series of managerial performance metrics. Underpinned by simple, technical and bureaucratic controls in the workplace, managerial capitalism was and partially remains as a set of firm level management practices and associated human resource strategies and business system ideology. O'Sullivan's (2000) historical evaluation of corporate growth and contemporary 
development provides the contextual material necessary to establish the argument that to legitimise and sustain shareholder capitalism managerial practice has to be re-aligned exclusively towards owner interests. These do reflect the theory of shareholder value but more significantly it is the PEBM that creates and sustains shareholder value and which requires a 'downsize and distribute' approach away from a wider group of stakeholders towards key private equity shareholders. However, many American and the vast majority of German firms and the majority of those in many other business systems remained operationally wedded to national variants of managerial capitalism on the Chandlerian model. So across business systems the efficiency claims of the PEBM while contentious and controversial are recognised but for some actors and institutions they remain socially inappropriate and therefore less legitimate.

\section{Outline discussion of private equity in other varieties of capitalism}

Beyond the liberal market business systems of countries such as Australia, the UK and the USA the varieties thesis implies that the PEBM will be less developed and treated with greater hostility in more coordinated business systems. While this might have been true for Germany in the last days of the SPD regime under Merkel the situation is now different. The PEBM continues to find scrutiny in Germany but as the EU's most well developed stakeholder economy comes to terms with persistent unemployment and inward FDI private equity and more specifically venture capitalists are winning the support of business leaders and politicians. The economics Secretary, Michael Gloss is particularly supportive in the face of German institutional investors putting more of their funds into German controlled private equity firms whilst the latter in-league with the American Chamber of Commerce in Germany lobby for investment taper relief to continue on the current UK model. In contrast SPD members of the coalition government remain concerned about the $€ 1.5$ billion that tax write offs cost the German taxpayer every year. The German private equity and venture capital association argue that German owned private equity firms raised $€ 2$ billion in support of the PEBM in 2006, a 20\% rise on 2005 (BVK 2007). This rate of growth suggests that the model is embedded and likely to develop and extend further over the next couple of years. Similarly in France a French owned sector is well developed with Eurazeo appearing as the leading player having made a recent bid for the conglomerate firm Vivendi. The French private equity association suggests that private equity investors based in France invested $£ 7.1$ billion compared with the UK figure of $£ 22$ billion in 2006 . The evidence indicates that the vast majority of French private equity investment is invested in France (AFIC (2007). In addition the prevailing philosophy of private equity in France is more pluralistic than in the UK with at least $20 \%$ of private equity owned firms offering 'sweet equity' to managers and non-managers.

In Japan private equity investment has barely taken root accounting for about $1 \%$ of Japanese economic activity in 2006, in contrast the PEBM is well developed in other Asia Pacific markets such as Singapore and Taiwan. The main impediment to the diffusion of the PEBM in Japan is not necessarily managerial or public hostility but a lack of financial sophistication in the established management class. In addition the tradition of conglomerate firms in Japan makes owners reluctant to see firms broken up; however, established Japanese firms such as Toshiba ceramics have been acquired by private equity. In the language of the PEBM terms such as under performance in the Japanese business system is a largely untapped resource precisely because of the break-up and sale and lease back possibilities that conglomerate ownership can provide. As with South Korea the 
Japanese government is encouraging the creation of a domestically owned private equity sector to replace international firms that are in the main American and British.

In China about $90 \%$ of corporate finance is provided by bank loans and the PEBM is poorly developed but private equity investment in mainland Chinese business has doubled in value between 2005 and 2006 to $\$ 7$ billion. Beyond the domestic economy the Chinese government is pursuing a private equity FDI strategy and has recently placed $\$ 3$ billion of its foreign exchange reserves with Blackstone, the US private equity group in an effort to secure greater returns than they receive from US Treasury bills. Similar strategies are being developed in the Indian business system particularly by conglomerate firms such as Tata that have openly adopted the PEBM to secure its merger and acquisition strategies domestically and internationally. So while this evidence is summative and general it is possible to conclude that the PEBM is well developed across business systems and on this point it is worth considering the growth of private equity investment in the UK over the past 5 years which has seen exponential growth in fund size, returns and size of acquisitions.

Evaluating the PEBM in this way may extend the varieties of capitalism thesis and push it beyond the static sterility of framework over innovation. This is the case because the emergence then diffusion of the PEBM across business systems will have implications for the theoretical analysis of institutional frameworks which will require systematic empirical evaluation. First, greater investor engagement in strategy and operations post-acquisition suggests that the concept of 'strategic fit' between business and HR strategies will have to be further refined to accommodate the PEBM. For example, the pressure of efficient capital markets is becoming as or in some cases more significant than competitive pressures that flow from efficient product markets. Over the short term, cash flow is becoming more important than productivity or the quality of working life, a pressure that pushes organisations and managers towards particular courses of action as best practice, for example, funding acquisitions on the PEBM. Second, the presence and impact of convergent business strategies and practices that culminate in the national diffusion of the PEBM may compel business systems, established sectors and firms therein to converge towards a homogeneous organizational pattern of best practice for optimal efficiency as defined by the efficiency of capital markets thesis. That is, to avoid becoming a target of private equity acquisition or to grow in size without hurting shareholder value evidence suggests non private equity firms gradually adopt aspects of the debt leverage model. BA is part of a private equity dominated consortium bidding for Iberia the Spanish national airline, similarly Tata, is funding its acquisition of Corus on the private equity model, that is using the Corus assets (property and pension funds) as leverage rather than its own funds. In Germany, Deutsche Telecom, which is part owned by an American private equity firm, is embroiled in a battle with trade unions as it seeks to downsize its operations on the PEBM and transfer $40 \%$ of its employees to a lower cost subsidiary employer.

\section{The PEBM: implications for human resource management some initial empirical findings}

The material reported on in this section draws on primary research on private equity ownership, business strategies and labour management and a sector mapping survey undertaken for submission to the Treasury Select Committee on private equity and commissioned submissions to the Financial Services Authority discussion paper on private equity (FSA 2006). In addition to this the findings draw on interviews with the GMB and 
UNITE trade unions and interviews with trade union representatives whose employers have been transferred to private equity owned businesses and four fund managers employed in UK based private equity partnerships. For comparative purposes three interviews were held with the director and director of European and international affairs at the Confederation of German Employers (BDA).

Turning from theory to the empirical evaluation of the PEBM and employment relations much of the current media and academic discussion is couched implicitly or in terms of potential impact and in many respects trade union campaigns are ahead of the academic community. Prominent contributions to the literature discuss the impact of shareholder value as a governance ideology on finance and ownership strategies in established features of short-termism in the British business system such as financial engineering and growth strategies centred on merger and acquisition activity, (Bach 2005, pp. 24-26; Pendleton and Deakin 2007). Alternatively, many commentators lump the evaluation of private equity in with shareholder capitalism or shareholder value often erroneously linking the two to O'Sullivan (2000). At the headline level, private equity firms do operate within the ideology and established performance index of short-termism but it is necessary to say more than this, namely that the short term investment strategy within the PEBM is a threat both directly and indirectly to sustainable company growth and employment and investment in the form of research and development and innovation, (TSC 2007). The constant drive for short-term financial returns measured on a weekly or monthly metric creates an operational situation where downward pressures on wage levels and terms and conditions of employment may not lead immediately to job loses but move the employment relations framework towards the 'lower road'. Similarly, in terms of operating performance, profitability can be boosted regularly by short-term sweating or even reducing the level of capital investment and investment in employee development, see media reports on The AA, Bird's Eye, Gate Gourmet, Pizza Express and Travel Lodge, none of which have been challenged by private equity owners. (In the Treasury Select Committee hearings private equity owners appeared unconcerned about this type of criticism.) The empirical material reported on in this part of the paper identifies the direct and indirect effects of the PEBM under three headings - managerial remuneration and distribution, impact on established patterns of IR/HR at the workplace and organisational consolidation and downsizing.

\section{Managerial remuneration and distribution}

Case studies revealed two issues of interest under this heading - executive remuneration and pension scheme provision. Previous sections of the paper have established that in theory and often in practice the PEBM is inherently short term in focus in that its organisational rationale is to reduce operating costs to secure cash flow and make a business an attractive 'sell-on' proposition. One feature of this process is either the introduction or further development of stratified management remuneration systems in an acquired firm. Interviews with operational managers and fund managers found that so-called equity incentive packages often become one component in performance management systems where salary (that is, money) represents only a small part of a wider remuneration system, interviews suggest that at the time the split between salary and equity incentive package was in the region of 30:70. In effect management teams are incentivised through agency approaches to operate like business owners by the use of share option schemes and participation in management buy-ins within a private equity management buy-out. Not only does this encourage management to consider share price 
and short-term returns above all else but in addition this development contributes to greater disparity of income as corporate level incomes increase significantly faster than those of worker grade employees often despite increased productivity and profitability. Reinforcing the significance of this point, interview evidence and 'sight of' contract agreements revealed that as more management remuneration is placed in equity incentive packages it is often the case that stock options are back dated and future geared towards a target share price. ${ }^{2}$ As long as these shares are held for a period of 2 years the taxation breaks enjoyed by private equity partners (fund managers) are extended to senior executives and middle level management employees. Thus, however much academics may criticise rational actor approaches when its financial rewards are placed in front of you it is easy to see why managers find it so attractive, for example four senior managers at 'QinetiQ' who clubbed together to borrow about half a million pounds to secure 3\% of the privatised defence firms equity capital have recently secured a $20,000 \%$ return on their investment (NAO 2007).

The second area of concern is company pension schemes. Before detailing the issues it is important to point out that employee contributions via PAYE deductions into a company pension scheme is saving or deferred pay. This issue is often lost in more abstract discussion of pension fund defaults due to under funding by an employer.

Recently in several private equity 'take private' acquisitions, for example Alliance Boots, the buyers have announced an intention to borrow - leverage the purchase by using 'hard assets' (property and pension schemes) as collateral.

Interviews with fund managers, trade union officials and line managers uncovered several organisational, managerial and HR issues that flow from this development. First, as an emergent best practice many new private equity owners choose to under fund an existing pension scheme because of high levels of leverage and the use of the pension scheme as collateral. For example, one private equity bid for Sainsbury's collapsed because the scheme is currently in deficit to the tune of $£ 400$ million, a deficit that could grow to over $£ 3$ billion as a result of the proposed private equity takeover. Failure to agree on the funding gap resulted in the proposed deal falling through, as pension trustees felt unable to recommend the deal to shareholders. Second, pension liabilities although they relate to previously earned wages and salaries are in accountancy terms defined as 'unsecured creditors' who are someway down the queue in the case of corporate insolvency. An evaluation of recent applications to the pension protection fund and the financial assistance scheme conducted for this research found 59 pension funds associated with private equity in the financial assistance scheme and a further 38 in the pension protection scheme. In addition to this there is an unknown number of private equity controlled firms where buyers have placed pension fund schemes in less solvent subsidiary operations which in many cases caused union members to lose all or part of their pensions (GMB 2007). Regulation wise the provisions of the 2004 Pensions Act are designed to prevent this process, however the pension regulator has to make a fine judgement about such 'organisational re-structuring' as deliberate 'dumping' or merely 'more risky re-structuring'. The key point is that without the burden of a pension scheme cash flow improves and a firm becomes immediately more profitable for its private equity owners who once they have sold the business can leave an under funded pension scheme behind in a less solvent subsidiary. The need for this type of risky re-structuring may be done away with by a third empirical finding uncovered in the secondary private equity market. There is an emerging market for pension scheme buy-outs, fronted by insurance providers and private equity providers. Under this scheme a private equity firm, post-acquisition is able to 'off-load' its pension liabilities to an insurer or a bulk annuities group in return for 
a premium payment. Insurer's make their margin through the economies of scale and scope that result from one organisation running several pension schemes. De-coupling the pension scheme from the firm will again boost revenues.

\section{PEBM and established terms and conditions of employment}

The challenge for trade unions in collective bargaining and individual employees centres on the issue of prior consultation with respect to the organisational and managerial developments described above. This is the case because TUPE Regulations 2006 do not cover business transfers through share purchases, that is where a company name remains intact through a take private deal such as those that funded Debenham's, EMI, or Alliance Boots, but majority ownership changes. In this situation no prior disclosure is necessary. In addition to this, private equity owners have argued that performance management changes to terms and conditions of employment are not related to the transfer of business but to new incentivised forms of HRM. In many cases bargaining agreements and pension funds will be unaffected by private equity purchases or the PEBM. However, there is a dearth of independent academic empirical work on this issue precisely because private equity firms refuse all requests for access other than for work they commission. Evidence that is available and which can be regarded as impartial reveals that in PEBM controlled firms $40 \%$ of managers are hostile to trade unions with only $10 \%$ of the survey population supportive (Thornton 2007).

The fact that TUPE regulations do not apply to business transfers through the majority sale of shares in effect allows employers to de-recognise collective bargaining agreements and introduce 'substitution' policies sometimes despite considerable employee opposition. In at least two of the case studies reported on here (a car breakdown service provider and a chain of car parks) trade union opposition did subsequently result in agreement to re-recognise and the cancellation of the de-recognition decision. In contrast with some of the established literature findings on non-unionism and de-recognition (McLoughlin and Gourley 1994; Claydon 1997) the private equity employer (the same in both cases) made no attempt to improve on the established terms and conditions of employment and neither were they taking advantage of low union density or apathetic membership. In addition to this the private equity installed management choose not to devise or develop any non union representation arrangements common in more established non union employers, (see Gollan 2007, pp. 89-91). The issue of de-recognition is further compounded because trade unions, the pension regulator and individuals face a transparency issue relating to who actually owns a company acquired by private equity. Both the GMB trade union and the UNITE trade union made it clear at the Treasury Select Committee that these protections and respect for established features of collective bargaining agreements can only be achieved by improved government regulation and or changes to UK and EU law, (TSC/UNITE 2007; TSC/GMB 2007).

\section{Organisational consolidation and downsizing}

In the vast majority of merger and acquisition cases firms usually resort to some form of consolidation and restructuring that results in job losses. Such restructuring is unfortunate but in cases beyond the PEBM information and consultation regulations over redundancy, TUPE regulations and any collective bargaining agreements in place are usually respected. In the case of the PEBM, acquisition is fuelled by debt and considerations of short-term cash flow to meet interest payments, because of this overriding requirement acquired firms 
are usually examined as a bundle of assets that can be unbundled through the sale of peripheral units, the sale and lease-back of property or transport units, pension scheme de-coupling, etc. The main organisational effect of these strategies is redundancy, downsizing, closure and tighter HR systems at the workplace. That is, in contrast to merger and acquisitions focussed on the longer term consolidation of a sector say for example that which occurred in retail banking in the late 1990s re-structuring is unlikely to expand and further develop a new company. ${ }^{3}$

There is a substantial literature investigating the economic effects of private equity management buy-outs that demonstrates a positive, if econometrically based association between re-newed and re-structured corporate organisation and the productivity and profitability of an acquired firm (see, for example, Rappaport 1998; Jensen and Murphy 1990). More recent contributions to this literature modify the line of argument slightly but while the established and contemporary studies draw out the implications of private equity control for the management of HR there is little specific mention or evaluation of HR policies and strategies. For example, Harris, Siegel and Wright 2005 found that buy-outs lead to more economically efficient use of resources, reduced agency costs and better management. Similarly, although Kaplan and Schoar (2005) conclude that the PEBM does secure better financial returns than those managed more traditionally the authors' state quite clearly that net of the 2 and 20 type fees the returns are broadly similar. This leads to the conclusion that whatever type of HR system was in place in PEPM backed firms in this study it made very little difference. Last, Martin, Casson and Nisar (2007) addresses the impact of the PEBM in terms of investor engagement with acquisitions, specifically strategies to secure high returns in respect of high risk investments. Almost as a modification of the neo-classical theory of the firm high return $(20 \%+)$ is in this study seen as a factor return for risk and the case study material that the authors' present evaluates the extent to which private equity investors play an active role in investee companies beyond their obvious financial role. This includes a more hands-on management role but little or no evaluation of what this entails. Last, Hall (2007) demonstrates that methodological weaknesses in surveys commissioned by the private equity sector make their claims of a positive effect of private equity on employment in the USA and across Europe 'effectively worthless', for example some surveys include estimates and others include venture capital and start-up capital along with private equity buy-outs. Moreover, many surveys are self selecting in terms of reporting and inclusion. These points are particularly telling because private equity firms will seek out acquisitions that have good growth and cash flow potential on the basis of the PEBM, therefore in the short-term they are likely to grow faster than the average firm not subject to the rationale of the PEBM (TSC 2007).

The case studies conducted for this research identify two sets of findings at firm level that help to explain the meanings of 'improved performance' and 'better management'. First, operational improvements - what specialists in HRM term performance management - flow from a reduction in managerial discretion and an associated re-alignment of investor and owner interests with those of management. While performance improvements were evident in most of the cases under evaluation it was measured in terms of improved cash flow and head count reductions over shorter term performance metrics described in the previous section. These case studies confirm most of the arguments presented by Thornton (2007) who found that management buy-outs on the PEBM first cut employment levels then expanded employment but found workers to be worse off than comparable private sector workers. In the cases examined for this paper deterioration resulted from the introduction of stricter performance management systems. 
Second, performance improvements could result from more overtly aggressive management of HR focussed on the application of lower road approaches that reduce working capital and 'sweat' capital and labour by reigning in workplace pluralism - the de-recognition of collective bargaining agreements described above. This has the effect of re-distributing rents away from employee and customer stakeholders, moving to a more unitarist but unsophisticated framework for workplace employee relations. For example, at the AA a well publicised case of private equity ownership it is a matter of public record that the private equity owners de-recognised the trade union, ended check-off arrangements and offered to pay staff subscriptions to a new 'staff association' and subsequently offered redundant staff an $£ 18,000$ take it or leave it deal that was reduced to $£ 12,000$ in the second round of redundancies. Under the terms of the de-recognised collective bargaining agreement longer serving employees could have received redundancy payments of up to $£ 50,000$. In total the AA made over 3,500 workers redundant ( $35 \%$ of the workforce) resulting in fewer patrol staff, a less comprehensive out of hours service and reduced cycle times for patrol staff to diagnose break-downs. In effect the latter has resulted in many AA members experiencing a tow not fix service as patrol staff have only 15 minutes per breakdown, that is if patrol staff think it will take more than 15 minutes to undertake a repair or re-start the vehicle it will be towed to a garage, (interview notes and TSC 2007). After a sustained trade union campaign the AA's private equity boss agreed to re-recognise the GMB trade union. However, when the AA and Saga merged late last year the new management of the combined group disassociated itself with the previous commitment of the AA management team to re-recognise the GMB union and cut off all negotiations. Similarly, at the Bird's Eye plant in Hull private equity owners closed the entire plant only 5 months after acquiring the site from Unilever for $£ 1$ billion. There was no consultation with the staff at all who both collectively via the recognised union and individually in letters from the management were told that the plant would be kept open (interview notes TSC 2007). Last, at a feminine hygiene products company's private equity owners abandoned the previous owner's policy of allowing workers aged $50+$ to draw their pensions with no actuarial reduction in benefits for early retirement where their jobs were made redundant in cases of plant closure (interview notes).

\section{Conclusions: institutional determinism or the convergent futurology of private equity?}

Is it acceptable however necessary it might be for academics to say they don't know what the answer is either theoretically or empirically? Is it acceptable however necessary on the basis of theoretical, institutional and empirical limitations for academics to come to relatively simple conclusions in respect of the three issues the paper set out to address? Probably not.

1. The emergence of the PEBM as a significant actor

Operating within the dominant literature sets that examine comparative business systems and developments therein the evaluation of private equity firms and the PEBM detailed in this paper demonstrate that each has the capacity to counter the accepted wisdom of national business systems as givens. The PEBM appears capable of operation in business systems that are more or less institutionally favourable and in Germany as in the UK governments have sought to facilitate the operation of the PEBM despite opposition from national stakeholder groups. For example, in the UK British based private equity owns or controls businesses 
that account for $9 \%$ of the employed population or about 2.4 million workers (ITUC 2007). In Germany in 2007 German based private equity controlled businesses that accounted for just over 1 million workers (BVK 2007). However, in both Germany and the UK 5 years ago the figures were much smaller. Thus, while on the one hand, the activities of the BVK - the German venture capital association - are more extensive than one might think, on the other hand in the UK where private equity is better developed only one FTSE top 100 firm is controlled by private equity.

2. Diffusion of a new business model and associated pressures

As an innovation the PEBM has, going forward, the potential to challenge established patterns of managerial capitalism and gradually become part of them. Competitively and institutionally national patterns of managerial capitalism are based on public equity markets whereas the PEBM is firmly located within the theory of efficient capital markets where risk is compensated by high returns. Once the PEBM becomes a best practice template it is likely to change the institutional and competitive behaviour of firms and the competitive and institutional character of national business. However, the extent to which isomorphism leans towards the competitive or the institutional will require systematic longitudinal evaluation, but is this claim an exaggeration? Just think about what has happened to established businesses in the UK this year - Prêt a Manger, Jaguar, Land Rover, Alliance Boots, EMI, Aston Martin, Derby County FC, Liverpool FC and Manchester City FC (and many more less well known but important businesses) all subject to private equity or at least private equity backed acquisitions in the form of take private deals.

3. Acquisition by private equity - the effects on HRM

The managerial and HR implications of the PEBM are theoretically obvious but in the absence of system empirical research less evident. However, the academic community are behind the curve in their attempts to force each of these into existing frameworks. Organisational implications centre on how the internationalisation of investment in private equity is changing the competitive and institutional rules of business to the extent that cash flow is more important than more traditional measures of competitiveness such as productivity and the quality of working life. In addition this makes it necessary for academics to think about further refining concepts such as 'strategic fit' between business strategies and HR strategies; that is, how might private equity ownership change existing business strategies? Managerial implications centre on more severe pressure towards short-termism and revenue generating strategies. The implications for HRM while not yet subject to convincing empirical evaluation suggest further division between managerial grades and senior executives and everyone else, particularly in the private sector. Original research suggesting a movement towards lower road strategies either directly or indirectly is common.

\section{Private equity, the PEBM and the private equity sector: significant factors in the British business system or hot topic for jobbing researchers}

The theoretical, institutional and empirical arguments and evidence detailed in this paper require more rigorous and sustained empirical evaluation. While this is the case it does not necessarily or automatically have to fall within the confines of established approaches precisely because they tell us how we understand what is going on which is not the same as how employees at the AA, Gate Gourmet, Travel Lodge, New Look, Alliance Boots, 
etc. are likely to experience private equity ownership organisationally and managerially. Contentious it may be but for the management of HR it is the PEBM that is significant. This is the case because as the material presented here demonstrates and that gleaned from some high profile cases illustrate the model and its associated business and HR strategies evidently remain even when a firm has been returned to the listed market.

\section{Acknowledgements}

Support of the Treasury Select Committee on Private Equity, the Financial Services Authority and the GMB trade union is gratefully acknowledged. An earlier version of this paper was presented at the Cardiff ERU Conference, September 2007.

\section{Notes}

1. Research supported by the ESRC (R000238350). The project team comprised Phillip Almond, Peter Butler, Ian Clark, Trevor Colling, Anthony Ferner, Len Holden, Michael Muller, all then at De Montfort University, Leicester and Tony Edwards King's College London. Specific findings were followed up and further developed by the author in work commissioned by the Financial Services Authority and the Treasury Select Committee in its examination of private equity. Case study interviews were facilitated and supported by the GMB trade union and fund managers in UK based private equity partnerships. Financial support administered by Jacqui Ward and office management by Jane Whitmarsh.

2. 'Sight of' means that during the interview process contracts of employment and the remuneration, target and bonus details of senior managers was made available. In addition to this several managers were happy to talk about their own incentive packages. But in both cases it was not possible to copy these contracts or show them to or talk to other managers about them.

3. In the interests of balance during the TSC sessions and in numerous media interviews Fund Managers from Permira regularly cited the investment in and expansion of the Travel Lodge chain of budget hotels as evidence that points away from an Asset Stripping strategy, and it was the case that during the period of PE ownership the chain did expand significantly its number of outlets with new investment money.

\section{References}

AFIC (2007), 'The French Private Equity Association, Activity Report, 2006-2007,' AFIC, available from: www.afic.asso.fr

Alchain, A., and Demsetz, H. (1972), 'Production, Information Costs and Economic Organization,' American Economic Review, 62, 777-795.

Bach, S. (2005), 'Personnel in Transition,' in Personnel Management in Transition, Managing Human Resources, ed. S. Bach, Oxford: Blackwell, pp. 3-44.

Berle, A., and Means, G. (1932), The Modern Corporation and Private Property, New York: Macmillan.

BVK (2007), Bundesverband Deutscher Kapitalbeteiligungesellschaften, German Private Equity and Venture Capital Association, BVK Statistics, available from: www.bvk-ev.de

Chandler, A. (1977), The Visible Hand: The Managerial Revolution in American Business, Cambridge: Cambridge University Press.

Clark, I. (2006), 'Another Third Way? VW and Trails of Stakeholder Capitalism,' Industrial Relations Journal, 37, 6, 593-607.

Clark, I. (2007), 'Private Equity and HRM in the British Business System,' Human Resource Management Journal, 17, 3, 218-226.

Claydon, T. (1997), 'Union Recognition: A Re-examination,' in Contemporary Industrial Relations: A Critical Analysis, ed. I. Beardwell, Oxford: Oxford University Press, pp. 151-175.

Colling, T., and Clark, I. (2002), "Looking for Americanness": Sector Effects in Engineering Process Plant Contracting,' European Journal of Industrial Relations, 8, 3, 301-325.

DiMaggio, P., and Powell, W. (1983), 'The Iron Cage Re-visited: Institutional Isomorphism and Collective Rationality in Organizational Fields,' American Sociological Review, 48, 161-173.

DiMaggio P., and Powell W. (eds.) (1991), The New Institutionalism in Organizational Analysis, Chicago, IL: University of Chicago Press. 
Dore, R. (2000), Stock Market Capitalism: Welfare Capitalism Japan and Germany versus the Anglo-Saxons, Oxford: Oxford University Press.

Ferner, A., Almond, P., Clark, I., Colling, T., Edwards, T., and Holden, L. (2004), 'The Dynamics of Central Control and Subsidiary Autonomy in the Management of Human Resources: Case Study Evidence from US MNC's in the UK,' Organization Studies, 25, 3, 363-391.

Financial Services Authority (FSA) (2006), 'Private Equity: A Discussion of Risk and Regulatory Engagement,' Discussion Paper, 06/6, November, FSA, London.

Folkman, P., Froud, J., Sukhdev, J., and Williams, K. (2006), 'Working for Themselves? Capital Market Intermediaries and Present Day Capitalism,' Centre for Research on Socio-cultural Change, University of Manchester, working paper series no. 25, available from: www.cresc.ac.uk

Freeman, R., Boxall, P., and Haynes, P. (2007), 'Introduction: The Anglo-American Economies and Employee Voice,' in What Workers Say: Employee Voice in the Anglo-American Workplace, eds. R. Freeman, P. Boxall and P. Haynes, New York: Cornell University Press, pp. 1-25.

Frege, C. (2005), 'Varieties of Industrial Relations Research: Takeover, Convergence or Divergence?' British Journal of Industrial Relations, 43, 2, 179-208.

Froud, J., and Williams, K. (2007), 'Private Equity and the Culture of Value Extraction,' Centre for Research on Socio-cultural Change, University of Manchester, working papers series no. 31, available from: www.cresc.ac.uk

GMB Union (2007), Private Equity's Broken Pension Promises, London: GMB.

Gollan, P. (2007), Employee Representation in Non-union Firms, London: Sage.

Hall, D. (2007), 'Methodological Issues in Estimating the Impact of Private Equity Buyouts on Employment,' Control Publication commissioned by the T \& G section of UNITE.

Hall, P., and Soskice, D. (2001), 'An Introduction to the Varieties of Capitalism,' in Varieties of Capitalism: The Institutional Foundations of Comparative Advantage, eds. P. Hall and D. Soskice, Oxford: Oxford University Press, pp. 1-71.

Harris, R., Siegel, D., and Wright, M. (2005), 'Assessing the Impact of Management Buyouts on Economic Efficiency: Plant Level Evidence from the UK,' Review of Economics and Statistics, 87, 1, 148-154.

Heery, E., and Frege, C. (2006), 'New Actors in Industrial Relations,' British Journal of Industrial Relations, 44, 4, 601-604.

International Trade Union Confederation (2007), Where the House Always Win: Private Equity, Hedge Funds and the New Casino Capitalism. Brussels, Belgium, June, available from: www.ituc-csi.org

Jensen, M. (1989), 'The Eclipse of the Public Corporation.' Harvard Business Review, September, 62-74.

Jensen, M., and Meckling, W. (1976), 'Theory of the Firm: Managerial Behaviour, Agency Costs and Ownership Structure,' Journal of Financial Economics, 3, 305-360.

Jensen, M., and Murphy, K. (1990), 'Performance Pay and Top-management Incentives,' The Journal of Political Economy, 98, 2, 225-264.

Kaplan, S., and Schoar, A. (2005), 'Private Equity Performance Returns, Persistence and Capital Flows,' Journal of Finance, 60, 4, 1791-1824.

Marris, R. (1964), The Economic Theory of Managerial Capitalism, London: Macmillan.

Martin, R., Casson, P., and Nisar, T. (2007), Investor Engagement - Investors and Management Practice Under Shareholder Value, Oxford: Oxford University Press.

McLoughlin, I., and Gourley, S. (1994), Enterprise without Unions: Industrial Relations in the Non-union Firm, Milton Keynes: Open University Press.

Means, G. (1930), 'The Diffusion of Stock Ownership in the United States,' Quarterly Journal of Economics, 44, 4, 561-600.

National Audit Office (NAO) (2007), 'The Privatization of QinetiQ,' 23 November. London: The Stationary Office, available from: www.nao.org.uk

O'Sullivan, M. (2000), Contests for Corporate Control: Corporate Governance and Economic Performance in the United States and Germany, Oxford: Oxford University Press.

Pendleton, A., and Deakin, S. (2007), 'Corporate Governance and Workplace Employment Relations: The Potential of WERS 2004,' Industrial Relations Journal, 38, 4, 338-355.

Pendleton, A., and Gospel, H. (2005), 'Markets and Relationships: Finance, Governance and Labour in the UK,' in Corporate Governance and Labour Management - An International Comparison, Oxford: Oxford University Press, pp. 59-84. 
Rappaport, A. (1998), Creating Shareholder Value: A Guide to Managers and Investors revised edition of the 1986 original, New York: The Free Press.

Shleifer, A., and Vishny, R. (1997), 'A Survey of Corporate Governance,' Journal of Finance, 52, 2 , $737-783$.

Thornton, P. (2007), 'Inside the Dark Box: Shedding the Light on Private Equity,' The Work Foundation, London.

Treasury Select Committee Tenth Report (TSCTR) (2007), Written and Oral Evidence, 12 June, 20 June, 3 July, Hansard Archive, available from: www publications parliament.uk

TSC/Amicus-UNITE (2007), Memorandum Submitted to the Treasury Select Committee, published by the TSC as 'Memorandum Submitted by Amicus,' June 2007.

TSC/GMB (2007), Report and Evidence submitted to the Treasury Select Committee on Private Equity as part of the GMB union submission, April 2007, published by the TSC as the 'GMB Memorandum of Submission,' June 2007.

Whitley, R. (1992), European Business Systems: Firms and Markets in their National Contexts, London: Sage.

Whitley, R. (1999), Divergent Capitalism: The Social Structuring and Change of Business Systems, Oxford: Oxford University Press.

Williamson, O. (1964), The Economics of Discretionary Behaviour: Managerial Objectives in a Theory of the Firm, Upper Saddle River, NJ: Prentice Hall.

Williamson, O. (1967), 'Hierarchical Control and Optimum Firm Size,' Journal of Political Economy, 75, 123-138.

Williamson, O. (1975), Markets and Hierarchies: Analysis and Anti-trust Implications, New York: The Free Press. 